\title{
Neurosonological examination: a non-invasive approach for the detection of cerebrovascular impairment in AD
}

\section{Barbora Urbanova ${ }^{1}$, Ales Tomek ${ }^{1}$, Robert Mikulik ${ }^{2}$, Hana Magerova ${ }^{1}$, Daniel Horinek ${ }^{3,4}$ and Jakub Hort ${ }^{1,4}$}

1 Department of Neurology, 2nd Faculty of Medicine, Motol University Hospital, Charles University, Prague, Czech Republic

2 Department of Neurology, International Clinical Research Center, St. Anne's University Hospital, Brno, Czech Republic

${ }^{3}$ Department of Neurosurgery, 1st Faculty of Medicine, Central Military Hospital, Charles University, Prague, Czech Republic

${ }^{4}$ International Clinical Research Center, St. Anne's University Hospital, Brno, Czech Republic

\section{Edited by:}

Ales Stuchlik, Academy of Sciences of the Czech Republic, Czech Republic

Reviewed by:

Lidia Alonso-Nanclares, Universidad Politécnica de Madrid, Spain

Jeffrey Thomas Duda, University of Pennsylvania, USA

David Baglietto-Vargas, University of California Irvine, USA

\section{*Correspondence:}

Barbora Urbanova, Department of Neurology, 2nd Faculty of Medicine, Motol University Hospital, Charles

University, V Uvalu 84, 15000 Prague 5, Czech Republic

e-mail: barbora.urbanova@gmail.com
There has been a growing interest in vascular impairment associated with Alzheimer's disease (AD). This interest was stimulated by the findings of higher incidence of vascular risk factors in AD. Signs of vascular impairment were investigated notably in the field of imaging methods. Our aim was to explore ultrasonographic studies of extra- and intracranial vessels in patients with $A D$ and mild cognitive impairment $(\mathrm{MCl})$ and define implications for diagnosis, treatment, and prevention of the disease. The most frequently studied parameters with extracranial ultrasound are intima-media thickness in common carotid artery, carotid atherosclerosis, and total cerebral blood flow. The transcranial ultrasound concentrates mostly on flow velocities, pulsatility indices, cerebrovascular reserve capacity, and cerebral microembolization. Studies suggest that there is morphological and functional impairment of cerebral circulation in AD compared to healthy subjects. Ultrasound as a non-invasive method could be potentially useful in identifying individuals in a higher risk of progression of cognitive decline.

Keywords: Alzheimer's disease, carotid ultrasound, cerebrovascular reserve capacity, neurosonology, transcranial ultrasound

\section{VASCULAR CHANGES AND ALZHEIMER'S DISEASE}

In an effort to reveal an etiopathogenic mechanism responsible for Alzheimer's disease (AD) many hypotheses have been postulated. Recent failures of candidate disease-modifying medications have led to many alternative theories of $\mathrm{AD}$ pathophysiology. Multiple studies suggest that the risk of $\mathrm{AD}$ is apart from other factors associated with midlife hypertension, diabetes mellitus, hypercholesterolemia, and other vascular risk factors (Breteler, 2000; Casserly and Topol, 2004; Gorelick, 2004; Shah et al., 2012). This association has led to a hypothesis that the vascular risk factors could play an important role in the genesis or in the progression of the disease, but even after years of research the role of vascular risk factors in $\mathrm{AD}$ remains a subject of discussion. Two principal theories were postulated. First, an impaired cerebral circulation from any cause leads to neurodegeneration (de la Torre, 2010). Second, vascular impairment from any cause (e.g., atherosclerosis) accelerates the rate of progression of neurodegeneration (Kalaria, 2002). The second theory is generally more accepted.

Various imaging methods were used to explore the signs of vascular impairment in $\mathrm{AD}$. White matter lesions in people above 65 years are associated with typical vascular risk factors and cognitive decline (Breteler et al., 1994; DeCarli et al., 2001; Wu et al., 2002). Higher extent of white matter lesions in MCI patients is associated with higher risk of progression of MCI to dementia of any kind (Wolf et al., 2000). In MCI patients, there is a regional hypoperfusion on SPECT examination in hippocampus, amygdala, and prefrontal cortex (Johnson et al., 1998), and in $\mathrm{AD}$ patients the perfusion is decreased in whole temporoparietal region and correlates with the disease severity (DeKosky et al., 1990) [AD patient with varying disease severity were divided into four groups according to mini-mental state examination (MMSE): $>24 ; 22-24 ; 15-21 ;<15$ ].

The objective of this review was to explore extracranial and transcranial ultrasound projects in $\mathrm{AD}$ patients. We tried to describe the pattern of functional or structural cerebrovascular impairment in $\mathrm{AD}$ as characterized by ultrasonography, and to summarize ultrasound parameters of cerebral circulation in $\mathrm{AD}$ vs. healthy control subjects or in AD patients longitudinally. We have discussed to what extent neurosonological examination could contribute to diagnosis, prevention, or treatment of $\mathrm{AD}$. We have also discussed whether there is a special pattern of circulation impairment, namely: Is AD associated with large vessel or, rather, small vessel disease? Are there predominant changes in a specific region of the brain? Is the incidence of microembolization higher in $\mathrm{AD}$, or is there a correlation of any parameter with disease progression?

\section{EXTRACRANIAL ULTRASOUND IN AD}

Main parameters that can be assessed by extracranial ultrasound are parameters of arterial wall [carotid intima-media thickness (IMT) and atherosclerotic plaques] and cerebral perfusion [total cerebral blood flow (CBF)].

\section{IMT AND CAROTID ATHEROSCLEROSIS}

Carotid IMT is defined as a distance between media-adventitia interface and intima-lumen interface measured on the common 
carotid artery, $1-2 \mathrm{~cm}$ proximally from bifurcation or, less frequently, on the internal carotid artery using automated analyzers implemented in most of the recent ultrasound devices. IMT is generally regarded as a marker of atherosclerosis and is a good predictor of future vascular events (Lorenz et al., 2007). To ensure the accuracy of IMT measurements, it is necessary to meet the technical, methodological, and operator related criteria (Gonzalez et al., 2008; Stein et al., 2009; Dogan et al., 2010; Society of Atherosclerosis Imaging and Prevention Developed in collaboration with the International Atherosclerosis Society, 2011; Touboul et al., 2012). Thanks to these criteria, the validity and reproducibility of IMT measurement are sufficient and IMT measurement is widely used in clinical practice as well as in the research, and is implemented in several guidelines for cardiovascular risk assessment (National Cholesterol Education Program (NCEP) Expert Panel on Detection, Evaluation, and Treatment of High Blood Cholesterol in Adults (Adult Treatment Panel III), 2002; de la Sierra et al., 2009; Stein et al., 2009; Greenland et al., 2010; Society of Atherosclerosis Imaging and Prevention Developed in collaboration with the International Atherosclerosis Society, 2011).

Atherosclerotic plaque is defined as a focal structure at a vessel wall protruding into the arterial lumen showing a thickness of more than $1.5 \mathrm{~mm}$ from the adventitia-media interface (Touboul et al., 2012). Number, proportions, and location of plaques as well as the presence of carotid stenosis caused by plaques need to be considered in the assessment of carotid atherosclerosis severity. The severity of carotid stenosis is quantified according to the flow velocities in the stenosis, residual lumen, and internal carotid artery/common carotid artery flow velocities ratio (Grant et al., 2003). There was a great emphasis on the standardization of the stenosis assessment for the reason of legitimate indication of carotid endarterectomy. The validity and reproducibility of the examination are sufficient for clinical as well as research purposes as long as the technical and personnel conditions are fulfilled (Mohler et al., 2012).

Epidemiological studies have evidenced that AD and VD share common risk factors, which include vascular risk factors such as hypertension, smoking, diabetes mellitus, and hypercholesterolemia (Casserly and Topol, 2004; Gorelick, 2004). These risk factors are also the principal risk factors of atherosclerosis (Greco et al., 2013); considering this, we would expect higher prevalence of large vessel disease in $\mathrm{AD}$ than in general population. The results of two large substudies of the prospective cohort of populationbased Rotterdam study are in accordance with this hypothesis (Hofman et al., 1997; van Oijen et al., 2007). Both of these substudies were focused on IMT and the degree of carotid (and generally peripheral) atherosclerosis in demented, both $\mathrm{AD}$ and vascular dementia (VD), and non-demented subjects. The cross-sectional analysis indicated that the more prominent carotid atherosclerosis the higher probability of dementia. This finding applies for $\mathrm{VD}$, where the association is strong because the atherosclerosis is the principle of the dementia itself, as well as for AD. The longitudinal analysis included measurements at baseline and after 7-9 years and showed that the increased IMT is in the short-term period associated with an increased risk of developing AD. Due to the increased mortality in population with increased IMT, the effect was attenuated in the long-term follow-up (van Oijen et al.,
2007). No difference in carotid atherosclerosis is found between $\mathrm{AD}$ and high vascular risk patients with VD. This implies that a certain level of impairment is present in both. Concerning the IMT, considered the incipient form of atherosclerosis, also no difference between AD and VD patients was found (Morovic et al., 2009).

In this context, the studies of cognitive decline in asymptomatic carotid stenosis are very interesting. High-degree carotid stenosis (70-99\%) or carotid occlusion can be associated with cognitive decline in patients without otherwise clinically evident cerebrovascular disease, making the term "asymptomatic" stenosis somewhat arguable (Johnston et al., 2004; Balucani et al., 2012; Chang et al., 2013). The severity of impairment depends on the quality of collateral blood supply; the character of cognitive decline is influenced by the side of stenosis given by the distinctive functions of cerebral hemispheres. In left-sided stenosis, the verbal memory impairment is more frequent, and in right-sided stenosis there is more prominent visuospatial deficit (Balucani et al., 2012; Zavoreo et al., 2013). Two possible processes are considered in the pathophysiology - silent microembolism or hypoperfusion (Sztriha et al., 2009; Demarin et al., 2012). The carotid endarterectomy or carotid stenting and following reperfusion can improve the mental functions; on the other hand, during both procedures, the microembolism and hypoperfusion can occur as well and cause worsening of the cognitive decline.

Although the IMT in AD is generally increased as compared to healthy population, it does not correlate with cognitive performance in cross-sectional trials (Modrego et al., 2008). In longitudinal studies, IMT and atherosclerosis severity in AD patients correlate with the progression of cognitive impairment (Silvestrini et al., 2009). The progression is faster in AD patients with higher degree of carotid stenosis than in $\mathrm{AD}$ patients without stenosis (Silvestrini et al., 2011). Abnormal values of IMT also significantly increase the risk of conversion from amnestic MCI to AD (Viticchi et al., 2012). In a longitudinal study involving a 6-month galantamine treatment of $\mathrm{AD}$, the patients with lower values of IMT at baseline had better response to treatment (Modrego et al., 2009), which suggests that AD patients with lower cerebrovascular burden have slower progression of disease. Details of ultrasound projects focused on IMT and carotid atherosclerosis in $\mathrm{AD}$ are listed in Table 1.

\section{TOTAL CBF}

Total CBF can be assessed by ultrasonography when measuring flow velocities in carotid and vertebral arteries and multiplying the result by the cross-sectional area of the vessels (average of systolic and diastolic areas). The results gained by this method are comparable to nitrous oxide and SPECT measurements giving the average CBF in a healthy subject of approximately $54 \mathrm{ml} / 100 \mathrm{~g} / \mathrm{min}$ (Schoning et al., 1994). Insignificant errors in the measurement of flow velocities and vessel diameter can give significant errors in the final blood flow, up to $10 \%$, but the accuracy and reproducibility of measurement are acceptable when repeated measurements are done and the average is calculated (Gill, 1985; Schoning and Scheel, 1996).

Total CBF reduces with age (Dorfler et al., 2000) and brain parenchymal volume (van Es et al., 2010). According to ultrasound 
Table 1 | IMT and carotid atherosclerosis.

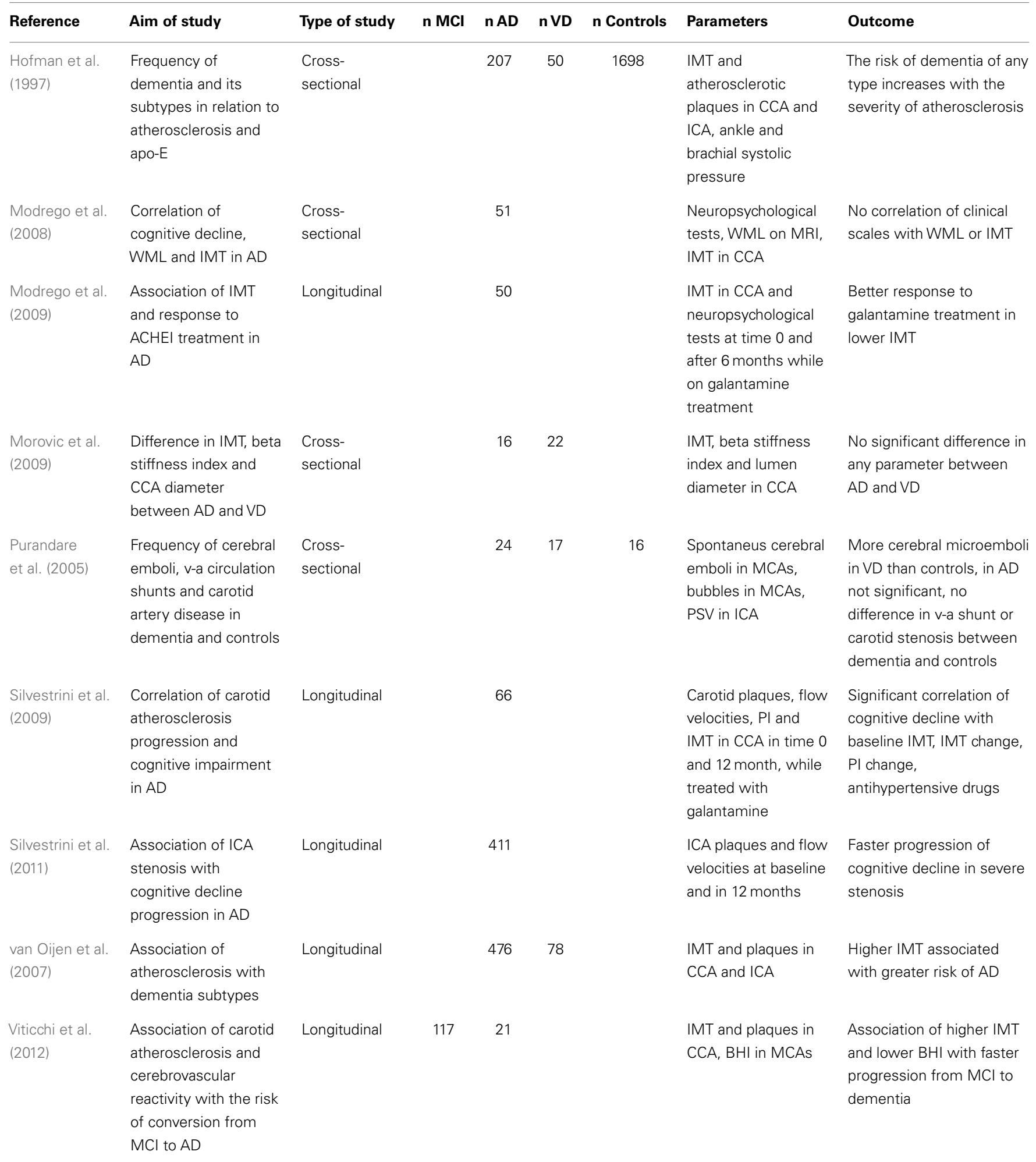

ACHEI, acetylcholine esterase inhibitor; AD, Alzheimer's disease; BHI, breath holding index; CCA, common carotid artery; ICA, internal carotid artery; IMT, intimamedia thickness; MCA, middle cerebral artery; MCl, mild cognitive impairment; MRI, magnetic resonance imaging; PI, pulsatility index; PSV, peak systolic velocity; $v$-a, venous-to-arterial; VD, vascular dementia; WML, white matter lesions. 
studies, the total CBF is significantly lower in both $\mathrm{AD}$ and VD than in healthy controls of the same age (Maalikjy Akkawi et al., 2003; Schreiber et al., 2005; Doepp et al., 2006). This corresponds with changes described for an ICA flow curve in $\mathrm{AD}$, where both systolic and diastolic velocities are lower compared to healthy individuals (Gusti et al., 2004). The association of total CBF with percentage of brain atrophy is weak (van Es et al., 2010). In an ultrasound study of three groups of patients with documented cerebral atrophy $(\mathrm{AD}$, VD, and cognitively normal subjects), the total CBF was significantly lower in patients with dementia than in those without a cognitive impairment. There was no significant difference between two types of dementia (Albayrak et al., 2006). Details of ultrasound projects focused on total CBF in AD are listed in Table 2.

\section{TRANSCRANIAL ULTRASOUND IN AD FLOW VELOCITIES, CEREBROVASCULAR RESISTANCE, AND CEREBROVASCULAR RESERVE CAPACITY}

The CBF curve in a transcranial ultrasound examination is characterized by two main flow velocities - peak systolic velocity and end diastolic velocity. These velocities can be measured in all major intracranial vessels - anterior, middle, and posterior cerebral arteries, vertebral arteries; and basilar artery. The mean flow velocity and indices describing the resistance of intracranial vessels can be derived from the flow curve. The reproducibility of flow velocities measurement is good when done by an experienced examiner (McMahon et al., 2007).

Many studies have found significantly lower flow velocities in AD compared to controls (Caamano et al., 1993; Roher et al., 2006, 2011; Sun et al., 2007; Vicenzini et al., 2007; Claassen et al., 2009; Stefani et al., 2009; Gucuyener et al., 2010). The most often studied vessel was the middle cerebral artery (MCA) while other major intracranial arteries were studied less frequently. The most often decreased velocity in MCA in $\mathrm{AD}$ patients compared to healthy controls was the mean flow velocity (Roher et al., 2006, 2011; Vicenzini et al., 2007; Claassen et al., 2009; Stefani et al., 2009), although not all results support these findings (Ries et al., 1993). Decreases in peak systolic and end diastolic velocities varied in different arteries (Caamano et al., 1993; Sun et al., 2007; Gucuyener et al., 2010). According to a large longitudinal study (Ruitenberg et al., 2005), subjects with higher velocities in MCA

Table 2 | Total cerebral blood flow.

\begin{tabular}{|c|c|c|c|c|c|c|c|c|}
\hline Reference & Aim of study & Type of study & n MCl & n AD & n VD & n Controls & Parameters & Outcome \\
\hline $\begin{array}{l}\text { Albayrak } \\
\text { et al. (2006) }\end{array}$ & $\begin{array}{l}\text { Comparison of cerebral } \\
\text { blood flow in demented } \\
\text { (AD, VD) and cognitively } \\
\text { normal subjects, both } \\
\text { with brain atrophy }\end{array}$ & Cross-sectional & & 9 & 9 & 10 & $\begin{array}{l}\text { Flow velocities and } \\
\text { cross-sectional area } \\
\text { of the vessel in ICAs } \\
\text { and VAs }\end{array}$ & $\begin{array}{l}\text { Total, anterior and right } \\
\text { CBF lower in dementia, no } \\
\text { difference between two } \\
\text { types of dementia }\end{array}$ \\
\hline $\begin{array}{l}\text { Doepp et al. } \\
\text { (2006) }\end{array}$ & $\begin{array}{l}\text { Possible differentiation of } \\
\text { AD and VD by various } \\
\text { extra- and intracranial } \\
\text { ultrasound parameters }\end{array}$ & Cross-sectional & & 20 & 20 & 12 & $\begin{array}{l}\text { Flow velocities and } \\
\mathrm{PI} \text { in MCAs, flow } \\
\text { velocities and } \\
\text { cross-sectional area } \\
\text { in ICAs and VAs, } \\
\text { cerebral circulation } \\
\text { time, global cerebral } \\
\text { blood volume }\end{array}$ & $\begin{array}{l}\text { No significant difference in } \\
\text { trans- and extracranial } \\
\text { ultrasound between AD } \\
\text { and VD }\end{array}$ \\
\hline $\begin{array}{l}\text { Gusti et al. } \\
\text { (2004) }\end{array}$ & $\begin{array}{l}\text { Comparison of carotid } \\
\text { flow velocities and flow } \\
\text { curve in AD and controls }\end{array}$ & Cross-sectional & & 18 & & 40 & $\begin{array}{l}\text { Flow velocities in } \\
\text { carotid arteries }\end{array}$ & $\begin{array}{l}\text { Lower cerebral vascular } \\
\text { filling in } A D\end{array}$ \\
\hline $\begin{array}{l}\text { Maalikjy } \\
\text { Akkawi et al. } \\
\text { (2003) }\end{array}$ & $\begin{array}{l}\text { Possibility of CBF volume } \\
\text { assessment by TCD, } \\
\text { difference between AD } \\
\text { and controls, correlation } \\
\text { with cognitive decline }\end{array}$ & Cross-sectional & & 50 & & 50 & $\begin{array}{l}\text { Flow velocities and } \\
\text { vessel diameter in } \\
\text { ICA and VA, } \\
\text { calculation of } \\
\text { cerebral blood flow }\end{array}$ & $\begin{array}{l}\text { Decrease in CBF volume in } \\
\text { AD compared to controls, } \\
\text { positive correlation } \\
\text { between dementia } \\
\text { severity and CBF }\end{array}$ \\
\hline $\begin{array}{l}\text { Schreiber } \\
\text { et al. (2005) }\end{array}$ & $\begin{array}{l}\text { CBF, cerebral circulation } \\
\text { time and cerebral blood } \\
\text { volume in AD, VD and } \\
\text { controls }\end{array}$ & Cross-sectional & & 20 & 20 & 12 & $\begin{array}{l}\text { Flow velocity and } \\
\text { cross-sectional area } \\
\text { of ICA and VA, time } \\
\text { of contrast agent } \\
\text { transfer from } \\
\text { ICA to IJV }\end{array}$ & $\begin{array}{l}\text { Difference in CBF and } \\
\text { transit time between } \\
\text { dementia and controls, no } \\
\text { difference in CBF volume } \\
\text { or between AD and VD }\end{array}$ \\
\hline
\end{tabular}

AD, Alzheimer's disease; CBF, cerebral blood flow; ICA, internal carotid artery; IJV, internal jugular vein; MCA, middle cerebral artery; MCI, mild cognitive impairment; $P I$, pulsatility index; TCD, transcranial Doppler; VA, vertebral artery; VD, vascular dementia. 
were less likely to develop AD. The question is - why the decrease should be most prominent in the MCA. We speculate this could be a consequence of pathological changes in $\mathrm{AD}$, where temporal and parietal lobes supplied by MCA are most affected. In this context, a comparison of healthy subjects and patients with MCI would be interesting, but the results are ambiguous (Roher et al., 2011). No significant difference in flow velocities was found between $\mathrm{AD}$ and $\mathrm{VD}$, neither there is a significant side asymmetry.

Unlike SPECT, the transcranial Doppler measures only flow velocities and not absolute blood flow, and the assessment of flow velocities is not helpful in an individual patient due to the wide range of normal values of flow velocities. The methods for assessment of regional cerebral perfusion or metabolism (SPECT, PET) have high sensitivity and specificity in distinguishing AD vs. normal controls (depending on the stage of the disease and method employed) based on characteristic perfusion or metabolism reduction in temporoparietal association cortex: SPECT can reach sensitivity of $65-96 \%$ and specificity of $80-87 \%$, PET can reach even sensitivity of $93-94 \%$ and specificity of $63-73 \%$ (Wollman and Prohovnik, 2003; Matsuda, 2007). These two methods can be used to make the clinical diagnosis of $\mathrm{AD}$ more accurate in some unclear cases.

A parameter describing autoregulation of cerebral perfusion is cerebrovascular reserve capacity, which reflects the capability of brain microvasculature to regulate cerebral perfusion in a reaction to various stimuli, thanks to constriction or dilatation. The most often used stimulus is a change of the arterial $\mathrm{CO}_{2}$ level that can be induced using breath holding, $\mathrm{CO}_{2}$ inhalation, or intravenous acetazolamide injection. Other less often used stimuli include hand movement, cognitive exercise, or blood pressure challenge (i.e., physical exercise). The cerebrovascular reserve capacity is expressed as the ratio of mean flow velocity in basal conditions and mean flow velocity in the conditions of a higher $\mathrm{CO}_{2}$ level. In normal brain, there is an increase in flow velocities. When breath holding is the stimulus, the ratio can be multiplied by the duration of breath holding and expressed as breath holding index (BHI). Cerebrovascular reserve capacity decreases with age (Peisker et al., 2010).

The cerebrovascular reserve capacity is in clinical practice routinely tested before revascularization procedures in carotid stenosis or occlusion. The established methods for cerebrovascular reserve capacity assessment are scintigraphic techniques such as SPECT and PET with the use of various radioactive tracer compounds, all of them evaluating the cerebral perfusion in basal conditions and after vasodilatory stimulus (acetazolamide injection or $\mathrm{CO}_{2}$ inhalation). In comparison with these direct techniques, the transcranial Doppler examination is an indirect assessment based on the relative increase in flow velocities after vasodilatory stimulus (usually acetazolamide injection, $\mathrm{CO}_{2}$ inhalation or breath holding). All three transcranial Doppler methods correlate very well to 133Xe SPECT (Bishop et al., 1986; Dahl et al., 1992; Muller et al., 1995) with the breath-holding method being the less accurate but sufficient for first screening examination (Markus and Harrison, 1992; Muller et al., 1995). Compared to scintigraphic techniques the ultrasound examination is non-invasive and inexpensive.
Concerning the cerebrovascular reserve capacity measured by transcranial Doppler in the MCA in $\mathrm{AD}$ patients, the results are more consistent than those for solely flow velocities. In $\mathrm{AD}$ patients, the reactivity to different stimuli in the MCA is significantly lower than in healthy controls (Provinciali et al., 1990; Bar et al., 2007; Lee et al., 2007; Vicenzini et al., 2007; Stefani et al., 2009). Only some studies with fewer subjects do not fully support these findings (Matteis et al., 1998; Claassen et al., 2009). In one of these studies, the result could be influenced by the selection of very mild AD cases (MMSE 25) (Claassen et al., 2009). In another study, it is not sufficiently described how the cognitive impairment was ruled out in control subjects (Matteis et al., 1998). One study proved a better cerebrovascular reserve capacity in $\mathrm{AD}$ than $\mathrm{VD}$, but the result was not statistically significant (Likitjaroen et al., 2009). Healthy subjects with higher cerebrovascular reserve capacity are less likely to develop a cognitive decline (AD or VD) (Ruitenberg et al., 2005). Although the impairment of cerebrovascular reserve capacity is more serious in VD, it seems that the microvasculature is altered in both main types of dementia (Bar et al., 2007; Vicenzini et al., 2007).

On the other hand, the hypercapnia challenge in SPECT and PET studies give ambiguous results without convincing evidence of decreased cerebrovascular reserve capacity in AD (Yamaguchi et al., 1980; Bonte et al., 1989; Kuwabara et al., 1992; Stoppe et al., 1995; Knapp et al., 1996; Jagust et al., 1997; Oishi et al., 1999; Pavics et al., 1999). However, it must be taken into account that in earlier publications, the diagnostic criteria for AD may differ from nowadays criteria and older devices may not give very accurate results (Glodzik et al., 2013).

Again the comparison with asymptomatic carotid stenosis or occlusion is interesting. In cases of high degree stenosis or occlusion with insufficient collateral blood supply, the chronic hypoperfusion exhausts the cerebrovascular reserve. This can be observed in different examination methods (Oka et al., 2013) including transcranial Doppler ultrasound examination using BHI (Balestrini et al., 2013; Zavoreo et al., 2013). The decrease of cerebrovascular reserve capacity correlates with the cognitive decline (Zavoreo et al., 2013).

The cerebrovascular reserve capacity of posterior cerebral artery in reaction to a visual stimulus was often tested. The function of occipital lobe should be preserved until late stages of AD. The results of such projects were ambiguous (Asil and Uzuner, 2005; Rosengarten et al., 2006, 2007; Gucuyener et al., 2010) and, thus, not differentiating AD from VD.

The reason for the decreased cerebrovascular reserve capacity is not entirely clear. In VD, the cause is probably a small vessel disease. In $\mathrm{AD}$, amyloid deposits represent the likely culprit - in cerebral amyloid angiopathy, the cerebrovascular reserve capacity is also compromised (Menendez-Gonzalez et al., 2011). Another hypothesis suggests the role of insufficient acetylcholine production necessary for vasodilatation. Therapeutic tests with acetylcholine inhibitors (galantamine or donepezil) demonstrated an increase in flow velocities and improvement of vessel reactivity in both VD and AD (Rosengarten et al., 2006; Bar et al., 2007; Ghorbani et al., 2010). In longitudinal follow-up studies, the BHI significantly correlated with neuropsychological tests - MMSE and Alzheimer's Disease Assessment Scale-cognitive subscale (ADAS-Cog) in AD 
Table 3 | Flow velocities, cerebrovascular resistance, and cerebrovascular reserve capacity.

\begin{tabular}{|c|c|c|c|c|c|c|c|c|}
\hline Reference & Aim of study & Type of study & n MCI & n AD & n VD & N Controls & Parameters & Outcome \\
\hline $\begin{array}{l}\text { Asil and } \\
\text { Uzuner (2005) }\end{array}$ & $\begin{array}{l}\text { Assessment of } \\
\text { CVRC in the } \\
\text { occipital lobe in } \\
\text { AD }\end{array}$ & Cross-sectional & & 15 & 12 & 9 & $\begin{array}{l}\text { Flow velocities in } \\
\text { PCAs during eyes } \\
\text { opened and eyes } \\
\text { closed }\end{array}$ & $\begin{array}{l}\text { No significant difference } \\
\text { neither in flow velocities at } \\
\text { rest nor at stimuli in three } \\
\text { groups; decreased reactivity } \\
\text { in VD at stimulus }\end{array}$ \\
\hline $\begin{array}{l}\text { Claassen et al. } \\
\text { (2009) }\end{array}$ & $\begin{array}{l}\text { Assessment of } \\
\text { cerebral } \\
\text { hemodynamics } \\
\text { impairment in } \\
\text { early stage AD }\end{array}$ & Cross-sectional & & 9 & & 8 & $\begin{array}{l}\text { Flow velocities in } \\
\text { MCA, blood } \\
\text { pressure, } \\
\text { cerebrovascular } \\
\text { resistance index }\end{array}$ & $\begin{array}{l}\text { Significantly reduced flow } \\
\text { velocities and increased } \\
\text { resistance in } A D\end{array}$ \\
\hline $\begin{array}{l}\text { Ghorbani et al. } \\
(2010)\end{array}$ & $\begin{array}{l}\text { Assessment of } \\
\text { the effect of } \\
\text { Donepezil on } \\
\text { cerebral blood } \\
\text { flow velocity in } \\
\text { AD patients }\end{array}$ & Longitudinal & & 11 & & & $\begin{array}{l}\text { Flow velocities in } \\
\text { PCA and MCA at } \\
\text { baseline, after } \\
4 \text { weeks of donepezil } \\
5 \mathrm{mg} \text { and after } \\
\text { another } 4 \text { weeks of } \\
\text { donepezil } 10 \mathrm{mg}\end{array}$ & $\begin{array}{l}\text { Increase in PSV and MFV in } \\
\text { MCA, and MFV and EDV in } \\
\text { PCA after } 10 \mathrm{mg} \text { treatment }\end{array}$ \\
\hline $\begin{array}{l}\text { Gucuyener } \\
\text { et al. (2010) }\end{array}$ & $\begin{array}{l}\text { CVRC in PCAs in } \\
\text { AD compared to } \\
\text { depressive } \\
\text { pseudo-dementia }\end{array}$ & Cross-sectional & & 11 & 13 & 10 & $\begin{array}{l}\text { Flow velocities in } \\
\text { both PCAs } \\
\text { simultaneously; in } \\
\text { steady state and } \\
\text { after a visual } \\
\text { stimulus }\end{array}$ & $\begin{array}{l}\text { Lower flow velocities at rest } \\
\text { and after stimulus in both } A D \\
\text { and depressive } \\
\text { pseudodementia then } \\
\text { controls. CVRC impaired in } \\
\text { AD, not in depressive } \\
\text { pseudodementia }\end{array}$ \\
\hline $\begin{array}{l}\text { Lee et al. } \\
(2007)\end{array}$ & $\begin{array}{l}\text { Assessment of } \\
\text { CVRC in } A D\end{array}$ & Cross-sectional & & 17 & & 17 & $\begin{array}{l}\text { Flow velocities and } \\
\mathrm{PI} \text { in MCA bilaterally } \\
\text { in normal conditions } \\
\text { and after } 5 \text { min of } \\
\text { rebreathing }\end{array}$ & $\begin{array}{l}\text { No difference in baseline MFV } \\
\text { and PI between subjects and } \\
\text { controls, CVRC significantly } \\
\text { decreased on both sides in } \\
\text { AD }\end{array}$ \\
\hline $\begin{array}{l}\text { Likitjaroen } \\
\text { et al. (2009) }\end{array}$ & $\begin{array}{l}\text { Comparison of } \\
C V R C \text { in } A D \text { and } \\
\text { VD }\end{array}$ & Cross-sectional & & 9 & 9 & & $\begin{array}{l}\text { Flow velocities in } \\
\text { MCA in normal } \\
\text { conditions and after } \\
1000 \mathrm{mg} \\
\text { acetazolamide i.v. }\end{array}$ & $\begin{array}{l}\text { Non-significantly better CVRC } \\
\text { in } A D \text { than VD }\end{array}$ \\
\hline
\end{tabular}


Table 3 | Continued

\begin{tabular}{|c|c|c|c|c|c|c|c|c|}
\hline Reference & Aim of study & Type of study & n MCl & n AD & n VD & N Controls & Parameters & Outcome \\
\hline $\begin{array}{l}\text { Matteis et al. } \\
\text { (1998) }\end{array}$ & $\begin{array}{l}\text { Comparison of } \\
\text { CVRC in AD and } \\
\text { VD }\end{array}$ & Cross-sectional & & 10 & 10 & 20 & $\begin{array}{l}\text { Flow velocities in } \\
\text { MCA during apnea, } \\
\text { hand movement and } \\
\text { verbal and design } \\
\text { discrimination }\end{array}$ & $\begin{array}{l}\text { CVRC to apnea lower in VD; } \\
\text { hand } \\
\text { movement - contralateral } \\
\text { increase in flow in AD and } \\
\text { controls, bilateral in VD; } \\
\text { bilateral response on } \\
\text { cognitive stimuli in AD and } \\
\text { VD, corresponding side } \\
\text { response in controls }\end{array}$ \\
\hline $\begin{array}{l}\text { Provinciali } \\
\text { et al. (1990) }\end{array}$ & $\begin{array}{l}\text { Comparison of } \\
\text { CVRC in AD, VD } \\
\text { and controls }\end{array}$ & Cross-sectional & & 20 & 20 & 25 & $\begin{array}{l}\text { Flow velocities in } \\
\text { MCA at rest, after } \\
\text { hyperventilation, } \\
\text { apnea and } 5 \text { min air } \\
\text { rebreathing }\end{array}$ & $\begin{array}{l}\text { Higher PI, lower velocity } \\
\text { decrease in hyperventilation } \\
\text { in both dementias; rest flow } \\
\text { velocities and response to } \\
\text { hypercapnia lower in VD than } \\
\text { AD or controls }\end{array}$ \\
\hline $\begin{array}{l}\text { Ries et al. } \\
\text { (1993) }\end{array}$ & $\begin{array}{l}\text { Utility of TCD in } \\
\text { differentiation of } \\
\text { AD and } \\
\text { multi-infarct } \\
\text { dementia }\end{array}$ & Cross-sectional & & 24 & 17 & 64 & $\begin{array}{l}\text { PSV and EDV in all } \\
\text { large intracranial } \\
\text { vessels bilaterally, } \\
\text { pulse curve in MCA }\end{array}$ & $\begin{array}{l}\text { No difference in PSV in all } \\
\text { three groups, difference in } \\
\text { MFV, EDV and effective } \\
\text { pulsatility range in VD } \\
\text { compared to AD or controls }\end{array}$ \\
\hline $\begin{array}{l}\text { Roher et al. } \\
\text { (2006) }\end{array}$ & $\begin{array}{l}\text { Comparison of } \\
\text { mean flow } \\
\text { velocities and PI } \\
\text { in intracranial } \\
\text { arteries in AD and } \\
\text { controls }\end{array}$ & Cross-sectional & & 25 & & 30 & $\begin{array}{l}\text { Flow velocities in } 16 \\
\text { different segments } \\
\text { of circle of Willis }\end{array}$ & $\begin{array}{l}\text { Higher Pls in } A D, \\
\text { non-significantly lower mean } \\
\text { flow velocities in } A D\end{array}$ \\
\hline $\begin{array}{l}\text { Roher et al. } \\
\text { (2011) }\end{array}$ & $\begin{array}{l}\text { Utility of TCD in } \\
\text { diagnosing and } \\
\text { preventing } A D\end{array}$ & Cross-sectional & 11 & 42 & & 50 & $\begin{array}{l}\text { Flow velocities in } 16 \\
\text { different segments } \\
\text { of circle of Willis }\end{array}$ & $\begin{array}{l}\text { Significant difference in MFV } \\
\text { and } \mathrm{PI} \text { in left siphon, left ICA } \\
\text { and right distal MCA between } \\
\text { AD and controls }\end{array}$ \\
\hline $\begin{array}{l}\text { Rosengarten } \\
\text { et al. (2006) }\end{array}$ & $\begin{array}{l}\text { Influence of } \\
\text { ACHEl treatment } \\
\text { on vasoregulation } \\
\text { in } A D\end{array}$ & Longitudinal & & 8 & & 16 & $\begin{array}{l}\text { Flow velocities in } \\
\text { PCA and MCA in rest } \\
\text { and at stimulation } \\
\text { (text reading) at } \\
\text { baseline, after } \\
4 \text { weeks of donepezil } \\
5 \text { mg and after } \\
\text { another } 4 \text { weeks of } \\
\text { donepezil } 10 \mathrm{mg}\end{array}$ & $\begin{array}{l}\text { Decrease in attenuation } \\
\text { parameter after } 10 \mathrm{mg} \text { in } \\
A D=\text { dose dependent } \\
\text { resolution of functional } \\
\text { vascular deficit }\end{array}$ \\
\hline $\begin{array}{l}\text { Rosengarten } \\
\text { et al. (2007) }\end{array}$ & $\begin{array}{l}\text { Comparison of } \\
\text { activation-flow } \\
\text { coupling in AD, } \\
\text { VD and controls }\end{array}$ & Cross-sectional & & 15 & 10 & 15 & $\begin{array}{l}\text { Flow velocities in } \\
\text { PCA and MCA in rest } \\
\text { and at stimulation } \\
\text { (text reading) }\end{array}$ & Lower increase in PSV in VD \\
\hline $\begin{array}{l}\text { Ruitenberg } \\
\text { et al. (2005) }\end{array}$ & $\begin{array}{l}\text { Correlation of } \\
\text { flow velocities } \\
\text { with cognitive } \\
\text { decline and } \\
\text { hippocampal } \\
\text { atrophy }\end{array}$ & Cross-sectional & & 13 & 1 & 1718 & $\begin{array}{l}\text { Flow velocities in } \\
\text { MCAs at rest and } \\
\text { after } 5 \text { min of } 5 \% \\
\mathrm{CO}_{2}\end{array}$ & $\begin{array}{l}\text { Greater PSV, MFV, EDV - less } \\
\text { likely dementia and bigger } \\
\text { hippocampus and amygdala } \\
\text { No association of CVRC and } \\
\text { presence of dementia }\end{array}$ \\
\hline
\end{tabular}


Table 3 | Continued

\begin{tabular}{|c|c|c|c|c|c|c|c|c|}
\hline Reference & Aim of study & Type of study & n MCI & n AD & n VD & N Controls & Parameters & Outcome \\
\hline $\begin{array}{l}\text { Silvestrini et al. } \\
\text { (2009), Stefani } \\
\text { et al. (2009) }\end{array}$ & $\begin{array}{l}\text { Comparison of } \\
\text { cerebral } \\
\text { hemodynamics in } \\
\text { AD and controls }\end{array}$ & Cross-sectional & & 40 & & 40 & $\begin{array}{l}\text { Flow velocities, } \mathrm{PI} \\
\text { and } \mathrm{BHI} \text { in } \mathrm{MCA}\end{array}$ & $\begin{array}{l}\text { Lower MFV, higher } \mathrm{PI} \text { and } \\
\text { lower } \mathrm{BHI} \text { in } \mathrm{MCA} \text { in } \mathrm{AD} \text { than } \\
\text { in controls }\end{array}$ \\
\hline $\begin{array}{l}\text { Vicenzini et al. } \\
\text { (2007) }\end{array}$ & $\begin{array}{l}\text { Comparison of } \\
\text { flow velocities, PI } \\
\text { and CVRC in AD, } \\
\text { VD, and controls }\end{array}$ & Cross-sectional & & 60 & 58 & 62 & $\begin{array}{l}\text { Flow velocities in } \\
\text { MCA in normal } \\
\text { conditions, after } \\
\text { hyperventilation and } \\
\mathrm{CO}_{2} \text { inhalation }\end{array}$ & $\begin{array}{l}\text { Lower MFV, higher } \mathrm{PI} \text { and } \\
\text { lower } \mathrm{CVRC} \text { in } \mathrm{AD} \text { and } \mathrm{VD} \\
\text { compared to controls }\end{array}$ \\
\hline $\begin{array}{l}\text { Viticchi et al. } \\
\text { (2012) }\end{array}$ & $\begin{array}{l}\text { Association of } \\
\text { carotid } \\
\text { atherosclerosis } \\
\text { and } \\
\text { cerebrovascular } \\
\text { reserve capacity } \\
\text { with the risk of } \\
\text { conversion from } \\
\mathrm{MCl} \text { to } \mathrm{AD}\end{array}$ & Longitudinal & 117 & 21 & & & $\begin{array}{l}\mathrm{IMT} \text { and plaques in } \\
\mathrm{CCA}, \mathrm{BHI} \text { in MCAs }\end{array}$ & $\begin{array}{l}\text { Association of higher IMT and } \\
\text { lower } \mathrm{BHI} \text { with faster } \\
\text { progression from } \mathrm{MCl} \text { to } \\
\text { dementia }\end{array}$ \\
\hline
\end{tabular}

ACA, anterior cerebral artery; ACHEl, acetylcholine esterase inhibitor; AD, Alzheimer's disease; BA, basilar artery; CAA, cerebral amyloid angiopathy; CVRC, cerebrovascular reserve capacity; DM, diabetes mellitus; EDV, end diastolic velocity; ICA, internal carotid artery; MCA, middle cerebral artery; MCl, mild cognitive impairment; MFV, mean flow velocity; PCA, posterior cerebral artery; PI, pulsatility index; PSV, peak systolic velocity; VD, vascular dementia.

(Silvestrini et al., 2006). MCI patients with pathological values of BHI have greater risk of converting to dementia than patients with normal values (Viticchi et al., 2012). Details of ultrasound projects focused on flow velocities and cerebrovascular reserve capacity in AD are listed in Table 3.

\section{SPONTANEOUS CEREBRAL MICROEMBOLIZATION AND PARADOXICAL EMBOLIZATION VIA RIGHT-LEFT SHUNTS}

Recent evidence suggests that cerebral microemboli can lead to a cognitive decline (Pugsley et al., 1994; Gaudet et al., 2009). Cerebral microemboli can originate from arterial sources or venous sources in setting of right-left shunts (intracardiac-foramen ovale patens, atrial septal defects). The spontaneous cerebral embolization can be monitored using a headframe with attached ultrasound probes for time periods of usually $1-24 \mathrm{~h}$. Right-left shunts are examined by intravenous injection of a microbubble agent (agitated saline or hydroxyethyl starch) and observing the presence of microbubbles in brain vessels using transcranial ultrasound at rest and during the Valsalva maneuver. The accuracy of right-left shunt assessment by transcranial Doppler ultrasound compared to the transesophageal echocardiography as a gold standard ranges from 68 to $100 \%$ according to the reports in literature, some of them claiming the transcranial Doppler method even more accurate (Nemec et al., 1991; Teague and Sharma, 1991; Di Tullio et al., 1993; Jauss et al., 1994; Job et al., 1994; Sastry et al., 2009). The sensitivity and reproducibility of the examination is highest when performed repeatedly (twice) with the use of Valsalva maneuver (Droste et al., 1999).

There were not many studies focused on spontaneous cerebral embolization in $\mathrm{AD}$. One work suggested that it is more frequent in patients with $\mathrm{AD}$ or $\mathrm{VD}$ than in healthy controls (Purandare et al., 2005). This suggestion was later confirmed by a larger case-control study (Purandare et al., 2006). In this particular project, there was no significant difference in the 
Table 4 | Spontaneous cerebral microembolization and paradoxical embolization via right-left shunts.

\begin{tabular}{|c|c|c|c|c|c|c|c|c|}
\hline Reference & Aim of study & Type of study & $\mathbf{n ~ M C l}$ & n AD & n VD & n Controls & Parameters & Outcome \\
\hline $\begin{array}{l}\text { Purandare } \\
\text { et al. (2005) }\end{array}$ & $\begin{array}{l}\text { Spontaneous cerebral } \\
\text { microemboli, v-a } \\
\text { circulation shunts and } \\
\text { carotid artery disease in } \\
\text { dementia and controls }\end{array}$ & Cross-sectional & & 24 & 17 & 16 & $\begin{array}{l}\text { Spontaneus } \\
\text { cerebral emboli in } \\
\text { MCAs, bubbles in } \\
\text { MCAs, PSV in ICA }\end{array}$ & $\begin{array}{l}\text { More cerebral microemboli } \\
\text { in VD than controls, in AD } \\
\text { not significant, no } \\
\text { difference in shunt or } \\
\text { carotid stenosis between } \\
\text { dementia and controls }\end{array}$ \\
\hline $\begin{array}{l}\text { Purandare } \\
\text { et al. (2006) }\end{array}$ & $\begin{array}{l}\text { Spontaneous cerebral } \\
\text { microemboli, v-a } \\
\text { circulation shunts and } \\
\text { carotid artery disease in } \\
\text { dementia and controls }\end{array}$ & Cross-sectional & & 85 & 85 & 150 & $\begin{array}{l}\text { Spontaneus } \\
\text { cerebral emboli in } \\
\text { MCAs, bubbles in } \\
\text { MCAs, PSV in ICA }\end{array}$ & $\begin{array}{l}\text { More cerebral microemboli } \\
\text { in VD and AD than controls, } \\
\text { no difference in shunt or } \\
\text { carotid stenosis between } \\
\text { dementia and controls }\end{array}$ \\
\hline $\begin{array}{l}\text { Purandare and } \\
\text { Burns (2009) }\end{array}$ & $\begin{array}{l}\text { Association of } \\
\text { spontaneous cerebral } \\
\text { microembolization with } \\
\text { dementia etiology, } \\
\text { dementia progression } \\
\text { and depression in } \\
\text { dementia or controls }\end{array}$ & $\begin{array}{l}\text { Cross-sectional } \\
\text { Longitudinal }\end{array}$ & & 85 & 85 & 150 & $\begin{array}{l}\text { Spontaneus } \\
\text { cerebral emboli in } \\
\text { MCAs, bubbles in } \\
\text { MCAs, PSV in ICA. } \\
\text { Neuropsychological } \\
\text { tests in time } 0 \text { and } \\
6 \text { months }\end{array}$ & $\begin{array}{l}\text { More cerebral microemboli } \\
\text { in AD and VD than } \\
\text { controls, more in } \\
\text { depression (both dementia } \\
\text { and controls). Association } \\
\text { with more rapid cognitive } \\
\text { decline in dementia }\end{array}$ \\
\hline
\end{tabular}

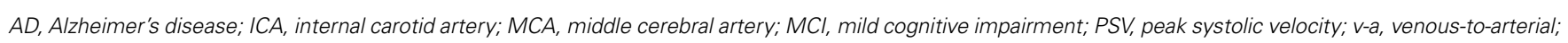
VD, vascular dementia.

Table 5 | Neurosonological parameters in AD - summary.

\begin{tabular}{|c|c|c|}
\hline Ultrasound parameter & Findings in AD & Conclusion \\
\hline IMT & $\begin{array}{l}\text { Increased IMT associated with increased short-term risk of } \\
\text { developing } A D \text {, converting from } M C I \text { to } A D \text {, and lower response to } \\
\text { galantamine treatment of } A D \\
\text { Correlates with the progression of } A D\end{array}$ & $\begin{array}{l}\text { In combination with other neurosonological methods } \\
\text { and vascular risks assessment can help to identify } \\
\text { patients in higher risk of faster progression of AD }\end{array}$ \\
\hline $\begin{array}{l}\text { Carotid } \\
\text { atherosclerosis }\end{array}$ & $\begin{array}{l}\text { Higher degree of carotid atherosclerosis associated with increased } \\
\text { short-term risk of developing } A D \text { and converting from } \mathrm{MCl} \text { to } A D \\
\text { Correlates with the progression of } A D\end{array}$ & $\begin{array}{l}\text { In combination with other neurosonological methods } \\
\text { and vascular risks assessment can help to identify } \\
\text { patients in higher risk of faster progression of AD }\end{array}$ \\
\hline $\begin{array}{l}\text { Total cerebral blood } \\
\text { flow }\end{array}$ & $\begin{array}{l}\text { Decreased in AD } \\
\text { Not dependent on brain atrophy } \\
\text { Longitudinal data not available }\end{array}$ & Inconclusive \\
\hline Flow velocities & $\begin{array}{l}\text { Variably decreased MFV in MCA in AD } \\
\text { Decreased flow velocities associated with increased risk of } \\
\text { developing AD }\end{array}$ & Inconclusive \\
\hline $\begin{array}{l}\text { Cerebrovascular } \\
\text { reserve capacity }\end{array}$ & $\begin{array}{l}\text { Decreased in } A D \\
\text { Decreased CVRC associated with increased risk of developing AD }\end{array}$ & $\begin{array}{l}\text { Best correlation with AD incidence and progression } \\
\text { among all neurosonological parameters }\end{array}$ \\
\hline
\end{tabular}

AD, Alzheimer's disease; IMT, intima-media thickness; MCA, middle cerebral artery; MCl, mild cognitive impairment; MFV, mean flow velocity.

incidence of carotid artery atherosclerosis - i.e., possible source of microembolization. Prevalence of patent foramen ovale in AD and VD cohort was $33 \%$ in this study, which is higher than usually reported $20-25 \%$ in general population (Hara et al., 2005), but no larger epidemiological studies of prevalence in $\mathrm{AD}$ were done. The same author found the association of spontaneous cerebral microembolization with more rapid cognitive decline in dementia (Purandare and Burns, 2009). Details of ultrasound projects focused on spontaneous and paradoxical embolization in $\mathrm{AD}$ are listed in Table 4.

\section{CONCLUSION}

The current evidence suggests that the brain perfusion in $\mathrm{AD}$ patients, in general, is impaired compared to healthy 
non-demented population. The most prominent ultrasonographical findings in extracranial circulation in $\mathrm{AD}$ patients show an increased IMT and higher burden of carotid artery atherosclerosis. The most often identified changes in intracranial circulation are lower flow velocities, lower total CBF (not explained by brain atrophy only), and most notably impaired cerebrovascular reserve capacity (Table 5). These findings seem to be valid for both $\mathrm{AD}$ and VD.

Ultrasonography of extra- and intracranial brain vessels can be helpful in $\mathrm{AD}$ patients to identify individuals who are in a higher risk of disease progression. Ultrasonography can be also useful for stratification of MCI patients and can contribute to predict the risk of conversion to $\mathrm{AD}$. The vascular risk factors surveillance and treatment in preclinical stages of $\mathrm{AD}$ is of great clinical importance and it could help to delay the development of cognitive decline in susceptible individuals. Ultrasonography is not especially beneficial in differentiating $\mathrm{AD}$ and $\mathrm{VD}$, because the microvasculature is altered in both types of dementia.

\section{AUTHOR CONTRIBUTIONS}

Barbora Urbanova, Ales Tomek, Robert Mikulik, and Jakub Hort took part in designing the aim and scope of the review. Barbora Urbanova, Ales Tomek, and Hana Magerova did the literature search. All the authors took part in detailed study and interpretation of the reviewed articles. All the authors took part in writing various sections of this article. Barbora Urbanova, Jakub Hort, Robert Mikulik, and Ales Tomek reviewed whole article.

\section{ACKNOWLEDGMENTS}

Supported by IGA MZ CR grant (No. NT/13319). Supported by GAUK grant (No 347711). Supported by the project FNUSAICRC (no. CZ.1.05/1.1.00/02.0123) from the European Regional Development Fund.

\section{REFERENCES}

Albayrak, R., Yaman, M., Uslan, I., Degirmenci, B., Acar, M., and Haktanir, A. (2006). Evaluation of total cerebral blood flow volume in cerebral atrophy. Neurosci. Lett. 399, 124-128. doi:10.1016/j.neulet.2006.01.039

Asil, T., and Uzuner, N. (2005). Differentiation of vascular dementia and Alzheimer disease: a functional transcranial Doppler ultrasonographic study. J. Ultrasound Med. 24, 1065-1070.

Balestrini, S., Perozzi, C., Altamura, C., Vernieri, F., Luzzi, S., Bartolini, M., et al. (2013). Severe carotid stenosis and impaired cerebral hemodynamics can influence cognitive deterioration. Neurology 80, 2145-2150. doi:10.1212/WNL. 0b013e318295d71a

Balucani, C., Viticchi, G., Falsetti, L., and Silvestrini, M. (2012). Cerebral hemodynamics and cognitive performance in bilateral asymptomatic carotid stenosis. Neurology 79, 1788-1795. doi:10.1212/WNL.0b013e318270402e

Bar, K. J., Boettger, M. K., Seidler, N., Mentzel, H. J., Terborg, C., and Sauer, H. (2007). Influence of galantamine on vasomotor reactivity in Alzheimer's disease and vascular dementia due to cerebral microangiopathy. Stroke 38, 3186-3192. doi:10.1161/STROKEAHA.107.492033

Bishop, C. C., Powell, S., Rutt, D., and Browse, N. L. (1986). Transcranial Doppler measurement of middle cerebral artery blood flow velocity: a validation study. Stroke 17, 913-915. doi:10.1161/01.STR.17.5.913

Bonte, F. J., Devous, M. D. Sr., Reisch, J. S., Ajmani, A. K., Weiner, M. F., Hom, J., et al. (1989). The effect of acetazolamide on regional cerebral blood flow in patients with Alzheimer's disease or stroke as measured by single-photon emission computed tomography. Invest. Radiol. 24, 99-103. doi:10.1097/00004424198902000-00002
Breteler, M. M. (2000). Vascular risk factors for Alzheimer's disease: an epidemiologic perspective. Neurobiol. Aging 21, 153-160. doi:10.1016/S0197-4580(99) 00110-4

Breteler, M. M., van Swieten, J. C., Bots, M. L., Grobbee, D. E., Claus, J. J., van den Hout, J. H., et al. (1994). Cerebral white matter lesions, vascular risk factors, and cognitive function in a population-based study: the Rotterdam Study. Neurology 44, 1246-1252. doi:10.1212/WNL.44.7.1246

Caamano, J., Gomez, M. J., and Cacabelos, R. (1993). Transcranial Doppler ultrasonography in senile dementia: neuropsychological correlations. Methods Find. Exp. Clin. Pharmacol. 15, 193-199.

Casserly, I., and Topol, E. (2004). Convergence of atherosclerosis and Alzheimer's disease: inflammation, cholesterol, and misfolded proteins. Lancet 363, 1139-1146. doi:10.1016/S0140-6736(04)15900-X

Chang, X. L., Zhou, H. Q., Lei, C. Y., Wu, B., Chen, Y. C., Hao, Z. L., et al. (2013). Association between asymptomatic carotid stenosis and cognitive function: a systematic review. Neurosci. Biobehav. Rev. 37, 1493-1499. doi:10.1016/j.neubiorev. 2013.05.011

Claassen, J. A., Diaz-Arrastia, R., Martin-Cook, K., Levine, B. D., and Zhang, R. (2009). Altered cerebral hemodynamics in early Alzheimer disease: a pilot study using transcranial Doppler. J. Alzheimers Dis. 17, 621-629. doi:10.3233/JAD2009- 1079

Dahl, A., Lindegaard, K. F., Russell, D., Nyberg-Hansen, R., Rootwelt, K., Sorteberg, W., et al. (1992). A comparison of transcranial Doppler and cerebral blood flow studies to assess cerebral vasoreactivity. Stroke 23, 15-19. doi:10.1161/01.STR.23.1.15

de la Sierra, A., Zamorano, J. L., and Ruilope, L. M. (2009). Application of hypertension guidelines in clinical practice: implementation of the $2007 \mathrm{ESH} / \mathrm{ESC}$ European practice Guidelines in Spain. J. Hypertens. Suppl. 27, S27-S32. doi:10.1097/01.hjh.0000356769.32130.95

de la Torre, J. C. (2010). The vascular hypothesis of Alzheimer's disease: bench to bedside and beyond. Neurodegener. Dis. 7, 116-121. doi:10.1159/000285520

DeCarli, C., Miller, B. L., Swan, G. E., Reed, T., Wolf, P. A., and Carmelli, D. (2001). Cerebrovascular and brain morphologic correlates of mild cognitive impairment in the National Heart, Lung, and Blood Institute Twin Study. Arch. Neurol. 58, 643-647. doi:10.1001/archneur.58.4.643

DeKosky, S. T., Shih, W. J., Schmitt, F. A., Coupal, J., and Kirkpatrick, C. (1990). Assessing utility of single photon emission computed tomography (SPECT) scan in Alzheimer disease: correlation with cognitive severity. Alzheimer Dis. Assoc. Disord. 4, 14-23. doi:10.1097/00002093-199040100-00002

Demarin, V., Zavoreo, I., and Kes, V. B. (2012). Carotid artery disease and cognitive impairment. J. Neurol. Sci. 322, 107-111. doi:10.1016/j.jns.2012.07.008

Di Tullio, M., Sacco, R. L., Venketasubramanian, N., Sherman, D., Mohr, J. P., and Homma, S. (1993). Comparison of diagnostic techniques for the detection of a patent foramen ovale in stroke patients. Stroke 24, 1020-1024. doi:10.1161/01.STR.24.7.1020

Doepp, F., Valdueza, J. M., and Schreiber, S. J. (2006). Transcranial and extracranial ultrasound assessment of cerebral hemodynamics in vascular and Alzheimer's dementia. Neurol. Res. 28, 645-649. doi:10.1179/016164106X130380

Dogan, S., Duivenvoorden, R., Grobbee, D. E., Kastelein, J. J., Shear, C. L., Evans, G. W., et al. (2010). Ultrasound protocols to measure carotid intima-media thickness in trials; comparison of reproducibility, rate of progression, and effect of intervention in subjects with familial hypercholesterolemia and subjects with mixed dyslipidemia. Ann. Med. 42, 447-464. doi:10.3109/07853890.2010. 499132

Dorfler, P., Puls, I., Schliesser, M., Maurer, M., and Becker, G. (2000). Measurement of cerebral blood flow volume by extracranial sonography. J. Cereb. Blood Flow Metab. 20, 269-271. doi:10.1097/00004647-200002000-00007

Droste, D. W., Reisener, M., Kemeny, V., Dittrich, R., Schulte-Altedorneburg, G., Stypmann, J., et al. (1999). Contrast transcranial Doppler ultrasound in the detection of right-to-left shunts. Stroke 30, 1014-1018. doi:10.1161/01.STR.30. 5.1014

Gaudet, J. G., Meyers, P. M., McKinsey, J. F., Lavine, S. D., Gray, W., Mitchell, E., et al. (2009). Incidence of moderate to severe cognitive dysfunction in patients treated with carotid artery stenting. Neurosurgery 65, 325-329. doi:10.1227/01. NEU.0000349920.69637.78 discussion 9-30,

Ghorbani, A., Chitsaz, A., Shishegar, M., and Akbari, M. (2010). Evaluation of the effect of donepezil on cerebral blood flow velocity in Alzheimer's disease. Neurosciences (Riyadh) 15, 172-176. 
Gill, R. W. (1985). Measurement of blood flow by ultrasound: accuracy and sources of error. Ultrasound Med. Biol. 11, 625-641. doi:10.1016/0301-5629(85)90035-3

Glodzik, L., Randall, C., Rusinek, H., and de Leon, M. J. (2013). Cerebrovascular reactivity to carbon dioxide in Alzheimer's disease. J. Alzheimers Dis. 35, 427-440. doi:10.3233/JAD-122011

Gonzalez, J., Wood, J. C., Dorey, F. J., Wren, T. A., and Gilsanz, V. (2008). Reproducibility of carotid intima-media thickness measurements in young adults. Radiology 247, 465-471. doi:10.1148/radiol.2472070691

Gorelick, P. B. (2004). Risk factors for vascular dementia and Alzheimer disease. Stroke 35, 2620-2622. doi:10.1161/01.STR.0000143318.70292.47

Grant, E. G., Benson, C. B., Moneta, G. L., Alexandrov, A. V., Baker, J. D., Bluth, E. I., et al. (2003). Carotid artery stenosis: gray-scale and Doppler US diagnosis - Society of Radiologists in Ultrasound Consensus Conference. Radiology 229, 340-346. doi:10.1148/radiol.2292030516

Greco, G., Egorova, N. N., Moskowitz, A. J., Gelijns, A. C., Kent, K. C., Manganaro, A. J., et al. (2013). Model for predicting the risk of carotid artery disease. Ann. Surg. 257, 1168-1173. doi:10.1097/SLA.0b013e31827b9761

Greenland, P., Alpert, J. S., Beller, G. A., Benjamin, E. J., Budoff, M. J., Fayad, Z. A., et al. (2010). 2010 ACCF/AHA guideline for assessment of cardiovascular risk in asymptomatic adults: a report of the American College of Cardiology Foundation/American Heart Association Task Force on Practice Guidelines. J. Am. Coll. Cardiol. 56, e50-e103. doi:10.1016/j.jacc.2010.09.001

Gucuyener, D. O., Yenilmez, C., Ayranci, U., Ozdemir, F., Uzuner, N., Ozkan, S., et al. (2010). An analysis of changes in cerebral blood flood velocities in depressive pseudo-dementia and Alzheimer disease patients. Neurologist 16, 358-363. doi:10.1097/NRL.0b013e3181a2eace

Gusti, S. I., Coteanu, M. I., and Gusti, A. S. (2004). Study of the cerebral vascular Doppler velocimetry and EEG in a group of 18 cases of Alzheimer's disease. Rom. J. Physiol. 41, 91-97.

Hara, H., Virmani, R., Ladich, E., Mackey-Bojack, S., Titus, J., Reisman, M., et al. (2005). Patent foramen ovale: current pathology, pathophysiology, and clinical status. J. Am. Coll. Cardiol. 46, 1768-1776. doi:10.1016/j.jacc.2005.08.038

Hofman, A., Ott, A., Breteler, M. M., Bots, M. L., Slooter, A. J., van Harskamp, F., et al. (1997). Atherosclerosis, apolipoprotein E, and prevalence of dementia and Alzheimer's disease in the Rotterdam Study. Lancet 349, 151-154. doi:10.1016/S0140-6736(96)09328-2

Jagust, W. J., Eberling, J. L., Reed, B. R., Mathis, C. A., and Budinger, T. F. (1997). Clinical studies of cerebral blood flow in Alzheimer's disease. Ann. N. Y. Acad. Sci. 826, 254-262. doi:10.1111/j.1749-6632.1997.tb48477.x

Jauss, M., Kaps, M., Keberle, M., Haberbosch, W., and Dorndorf, W. (1994). A comparison of transesophageal echocardiography and transcranial Doppler sonography with contrast medium for detection of patent foramen ovale. Stroke 25, 1265-1267. doi:10.1161/01.STR.25.6.1265

Job, F. P., Ringelstein, E. B., Grafen, Y., Flachskampf, F. A., Doherty, C., Stockmanns, A., et al. (1994). Comparison of transcranial contrast Doppler sonography and transesophageal contrast echocardiography for the detection of patent foramen ovale in young stroke patients. Am. J. Cardiol. 74, 381-384. doi:10.1016/0002-9149(94)90407-3

Johnson, K. A., Jones, K., Holman, B. L., Becker, J. A., Spiers, P. A., Satlin, A., et al. (1998). Preclinical prediction of Alzheimer's disease using SPECT. Neurology 50, 1563-1571. doi:10.1212/WNL.50.6.1563

Johnston, S. C., O'Meara, E. S., Manolio, T. A., Lefkowitz, D., O’Leary, D. H., Goldstein, S., et al. (2004). Cognitive impairment and decline are associated with carotid artery disease in patients without clinically evident cerebrovascular disease. Ann. Intern. Med. 140, 237-247. doi:10.7326/00034819-140-4-200402170-00005

Kalaria, R. (2002). Similarities between Alzheimer's disease and vascular dementia. J. Neurol. Sci. 203-204, 29-34. doi:10.1016/S0022-510X(02)00256-3

Knapp, W. H., Dannenberg, C., Marschall, B., Zedlick, D., Loschmann, K., Bettin, S., et al. (1996). Changes in local cerebral blood flow by neuroactivation and vasoactivation in patients with impaired cognitive function. Eur. J. Nucl. Med. 23, 878-888. doi:10.1007/BF01084360

Kuwabara, Y., Ichiya, Y., Otsuka, M., Masuda, K., Ichimiya, A., and Fujishima, M. (1992). Cerebrovascular responsiveness to hypercapnia in Alzheimer's dementia and vascular dementia of the Binswanger type. Stroke 23, 594-598. doi:10.1161/ 01.STR.23.4.594

Lee, S. T., Jung, K. H., and Lee, Y. S. (2007). Decreased vasomotor reactivity in Alzheimer's disease. J. Clin. Neurol. 3, 18-23. doi:10.3988/jen.2007.3.1.18
Likitjaroen, Y., Suwanwela, N. C., and Phanthumchinda, K. (2009). Vasoreactivity induced by acetazolamide in patients with vascular dementia versus Alzheimer's disease. J. Neurol. Sci. 283, 32-35. doi:10.1016/j.jns.2009.02.363

Lorenz, M. W., Markus, H. S., Bots, M. L., Rosvall, M., and Sitzer, M. (2007). Prediction of clinical cardiovascular events with carotid intima-media thickness: a systematic review and meta-analysis. Circulation 115, 459-467. doi:10.1161/ CIRCULATIONAHA.106.628875

Maalikjy Akkawi, N., Borroni, B., Agosti, C., Pezzini, A., Magoni, M., Rozzini, L., et al. (2003). Volume reduction in cerebral blood flow in patients with Alzheimer's disease: a sonographic study. Dement. Geriatr. Cogn. Disord. 16, 163-169. doi:10.1159/000071005

Markus, H. S., and Harrison, M. J. (1992). Estimation of cerebrovascular reactivity using transcranial Doppler, including the use of breath-holding as the vasodilatory stimulus. Stroke 23, 668-673. doi:10.1161/01.STR.23.5.668

Matsuda, H. (2007). Role of neuroimaging in Alzheimer's disease, with emphasis on brain perfusion SPECT. J. Nucl. Med. 48, 1289-1300. doi:10.2967/jnumed.106. 037218

Matteis, M., Silvestrini, M., Troisi, E., Bragoni, M., Vernieri, F., and Caltagirone, C. (1998). Cerebral hemodynamic patterns during stimuli tasks in multiinfarct and Alzheimer types of dementia. Acta Neurol. Scand. 97, 374-380. doi:10.1111/j.1600-0404.1998.tb05969.x

McMahon, C. J., McDermott, P., Horsfall, D., Selvarajah, J. R., King, A. T., and Vail, A. (2007). The reproducibility of transcranial Doppler middle cerebral artery velocity measurements: implications for clinical practice. Br. J. Neurosurg. 21, 21-27. doi:10.1080/02688690701210539

Menendez-Gonzalez, M., Garcia-Garcia, J., Calleja, S., Rojo, J., and Ribacoba, R. (2011). Vasomotor reactivity is similarly impaired in patients with Alzheimer's disease and patients with amyloid hemorrhage. J. Neuroimaging 21, e83-e85. doi:10.1111/j.1552-6569.2009.00438.x

Modrego, P. J., Rios, C., Perez Trullen, J. M., Errea, J. M., Garcia-Gomara, M. J., and Sanchez, S. (2008). The cerebrovascular pathology in Alzheimer's disease and its influence on clinical variables. Am. J. Alzheimers Dis. Other Demen. 23, 91-96. doi:10.1177/1533317507309274

Modrego, P. J., Rios, C., Perez Trullen, J. M., Garcia-Gomara, M. J., and Errea, J. M. (2009). Carotid intima-media thickness as a predictor of response to cholinesterase inhibitors in Alzheimer's disease: an open-label trial. CNS Drugs 23, 253-260. doi:10.2165/00023210-200923030-00006

Mohler, E. R. III, Gornik, H. L., Gerhard-Herman, M., Misra, S., Olin, J. W., and Zierler, E. (2012). ACCF/ACR/AIUM/ASE/ASN/ICAVL/SCAI/SCCT/SIR/SVM/SVS 2012 appropriate use criteria for peripheral vascular ultrasound and physiological testing part I: arterial ultrasound and physiological testing: a report of the American College of Cardiology Foundation Appropriate Use Criteria Task Force, American College of Radiology, American Institute of Ultrasound in Medicine, American Society of Echocardiography, American Society of Nephrology, Intersocietal Commission for the Accreditation of Vascular Laboratories, Society for Cardiovascular Angiography and Interventions, Society of Cardiovascular Computed Tomography, Society for Interventional Radiology, Society for Vascular Medicine, and Society for Vascular Surgery. J. Vasc. Surg. 56, e17-e51. doi:10.1016/j.jvs.2012.05.054

Morovic, S., Jurasic, M. J., Martinic Popovic, I., Seric, V., Lisak, M., and Demarin, V. (2009). Vascular characteristics of patients with dementia. J. Neurol. Sci. 283, 41-43. doi:10.1016/j.jns.2009.02.330

Muller, M., Voges, M., Piepgras, U., and Schimrigk, K. (1995). Assessment of cerebral vasomotor reactivity by transcranial Doppler ultrasound and breath-holding. Stroke 26, 96-100.

National Cholesterol Education Program (NCEP) Expert Panel on Detection, Evaluation, and Treatment of High Blood Cholesterol in Adults (Adult Treatment Panel III). (2002). Third Report of the National Cholesterol Education Program (NCEP) Expert Panel on Detection, Evaluation, and Treatment of High Blood Cholesterol in Adults (Adult Treatment Panel III) final report. Circulation 106, 3143-3421.

Nemec, J. J., Marwick, T. H., Lorig, R. J., Davison, M. B., Chimowitz, M. I., Litowitz, H., et al. (1991). Comparison of transcranial Doppler ultrasound and transesophageal contrast echocardiography in the detection of interatrial right-to-left shunts. Am. J. Cardiol. 68, 1498-1502. doi:10.1016/0002-9149(91)90285-S

Oishi, M., Mochizuki, Y., and Takasu, T. (1999). Regional differences in cerebrovascular reactivity to acetazolamide in Alzheimer's disease. J. Clin. Neurosci. 6, 380-381. doi:10.1054/jocn.1997.0085 
Oka, F., Ishihara, H., Kato, S., Oku, T., Yamane, A., Kunitugu, I., et al. (2013). Cerebral hemodynamic benefits after carotid artery stenting in patients with near occlusion. J. Vasc. Surg. 58, 1512-1517. doi:10.1016/j.jvs.2013.05.103

Pavics, L., Grunwald, F., Reichmann, K., Horn, R., Kitschenberg, A., Hartmann, A., et al. (1999). Regional cerebral blood flow single-photon emission tomography with $99 \mathrm{mTc}-\mathrm{HMPAO}$ and the acetazolamide test in the evaluation of vascular and Alzheimer's dementia. Eur. J. Nucl. Med. 26, 239-245. doi:10.1007/ s002590050383

Peisker, T., Bartos, A., Skoda, O., Ibrahim, I., and Kalvach, P. (2010). Impact of aging on cerebral vasoregulation and parenchymal integrity. J. Neurol. Sci. 299, 112-115. doi:10.1016/j.jns.2010.08.064

Provinciali, L., Minciotti, P., Ceravolo, G., Angeleri, F., and Sanguinetti, C. M. (1990). Transcranial Doppler sonography as a diagnostic tool in vascular dementia. Eur. Neurol. 30, 98-103. doi:10.1159/000117320

Pugsley, W., Klinger, L., Paschalis, C., Treasure, T., Harrison, M., and Newman, S. (1994). The impact of microemboli during cardiopulmonary bypass on neuropsychological functioning. Stroke 25, 1393-1399. doi:10.1161/01.STR.25.7. 1393

Purandare, N., and Burns, A. (2009). Cerebral emboli in the genesis of dementia. J. Neurol. Sci. 283, 17-20. doi:10.1016/j.jns.2009.02.306

Purandare, N., Burns, A., Daly, K. J., Hardicre, J., Morris, J., Macfarlane, G., et al. (2006). Cerebral emboli as a potential cause of Alzheimer's disease and vascular dementia: case-control study. BMJ 332, 1119-1124. doi:10.1136/bmj.38814. 696493.AE

Purandare, N., Welsh, S., Hutchinson, S., Riding, G., Burns, A., and McCollum, C. (2005). Cerebral emboli and paradoxical embolisation in dementia: a pilot study. Int. J. Geriatr. Psychiatry 20, 12-16. doi:10.1002/gps.1202

Ries, F., Horn, R., Hillekamp, J., Honisch, C., Konig, M., and Solymosi, L. (1993). Differentiation of multi-infarct and Alzheimer dementia by intracranial hemodynamic parameters. Stroke 24, 228-235. doi:10.1161/01.STR.24.2.228

Roher, A. E., Garami, Z., Alexandrov, A. V., Kokjohn, T. A., Esh, C. L., Kalback, W. M., et al. (2006). Interaction of cardiovascular disease and neurodegeneration: transcranial Doppler ultrasonography and Alzheimer's disease. Neurol. Res. 28, 672-678. doi:10.1179/016164106X130470

Roher, A. E., Garami, Z., Tyas, S. L., Maarouf, C. L., Kokjohn, T. A., Belohlavek, M., et al. (2011). Transcranial Doppler ultrasound blood flow velocity and pulsatility index as systemic indicators for Alzheimer's disease. Alzheimers Dement. 7, 445-455. doi:10.1016/j.jalz.2010.09.002

Rosengarten, B., Paulsen, S., Molnar, S., Kaschel, R., Gallhofer, B., and Kaps, M. (2006). Acetylcholine esterase inhibitor donepezil improves dynamic cerebrovascular regulation in Alzheimer patients. J. Neurol. 253, 58-64. doi:10. 1007/s00415-005-0926-5

Rosengarten, B., Paulsen, S., Molnar, S., Kaschel, R., Gallhofer, B., and Kaps, M. (2007). Activation-flow coupling differentiates between vascular and Alzheimer type of dementia. J. Neurol. Sci. 257, 149-154. doi:10.1016/j.jns.2007. 01.032

Ruitenberg, A., den Heijer, T., Bakker, S. L., van Swieten, J. C., Koudstaal, P. J., Hofman, A., et al. (2005). Cerebral hypoperfusion and clinical onset of dementia: the Rotterdam Study. Ann. Neurol. 57, 789-794. doi:10.1002/ana.20493

Sastry, S., MacNab, A., Daly, K., Ray, S., and McCollum, C. (2009). Transcranial Doppler detection of venous-to-arterial circulation shunts: criteria for patent foramen ovale. J. Clin. Ultrasound 37, 276-280. doi:10.1002/jcu.20564

Schoning, M., and Scheel, P. (1996). Color duplex measurement of cerebral blood flow volume: intra- and interobserver reproducibility and habituation to serial measurements in normal subjects. J. Cereb. Blood Flow Metab. 16, 523-531. doi:10.1097/00004647-199605000-00020

Schoning, M., Walter, J., and Scheel, P. (1994). Estimation of cerebral blood flow through color duplex sonography of the carotid and vertebral arteries in healthy adults. Stroke 25, 17-22. doi:10.1161/01.STR.25.1.17

Schreiber, S. J., Doepp, F., Spruth, E., Kopp, U. A., and Valdueza, J. M. (2005). Ultrasonographic measurement of cerebral blood flow, cerebral circulation time and cerebral blood volume in vascular and Alzheimer's dementia. J. Neurol. 252, 1171-1177. doi:10.1007/s00415-005-0826-8

Shah, N. S., Vidal, J. S., Masaki, K., Petrovitch, H., Ross, G. W., Tilley, C., et al. (2012). Midlife blood pressure, plasma beta-amyloid, and the risk for Alzheimer disease: the Honolulu Asia Aging Study. Hypertension 59, 780-786. doi:10.1161/HYPERTENSIONAHA.111.178962
Silvestrini, M., Gobbi, B., Pasqualetti, P., Bartolini, M., Baruffaldi, R., Lanciotti, C., et al. (2009). Carotid atherosclerosis and cognitive decline in patients with Alzheimer's disease. Neurobiol. Aging 30, 1177-1183. doi:10.1016/j. neurobiolaging.2007.11.008

Silvestrini, M., Pasqualetti, P., Baruffaldi, R., Bartolini, M., Handouk, Y., Matteis, M., et al. (2006). Cerebrovascular reactivity and cognitive decline in patients with Alzheimer disease. Stroke 37, 1010-1015. doi:10.1161/01.STR.0000206439. 62025.97

Silvestrini, M., Viticchi, G., Falsetti, L., Balucani, C., Vernieri, F., Cerqua, R., et al. (2011). The role of carotid atherosclerosis in Alzheimer's disease progression. $J$. Alzheimers Dis. 25, 719-726. doi:10.3233/JAD-2011-101968

Society of Atherosclerosis Imaging and Prevention Developed in collaboration with the International Atherosclerosis Society. (2011). Appropriate use criteria for carotid intima media thickness testing. Atherosclerosis 214, 43-46. doi:10.1016/ j.atherosclerosis.2010.10.045

Stefani, A., Sancesario, G., Pierantozzi, M., Leone, G., Galati, S., Hainsworth, A. H., et al. (2009). CSF biomarkers, impairment of cerebral hemodynamics and degree of cognitive decline in Alzheimer's and mixed dementia. J. Neurol. Sci. 283, 109-115. doi:10.1016/j.jns.2009.02.343

Stein, J. H., Korcarz, C. E., and Post, W. S. (2009). Use of carotid ultrasound to identify subclinical vascular disease and evaluate cardiovascular disease risk: summary and discussion of the American Society of Echocardiography consensus statement. Prev. Cardiol. 12, 34-38. doi:10.1111/j.1751-7141.2008.00021.x

Stoppe, G., Schutze, R., Kogler, A., Staedt, J., Munz, D. L., Emrich, D., et al. (1995). Cerebrovascular reactivity to acetazolamide in (senile) dementia of Alzheimer's type: relationship to disease severity. Dementia 6, 73-82.

Sun, Z. W., Zhu, Y. X., Liu, H. Y., Liu, J., Zhu, X. Q., Zhou, J. N., et al. (2007). Decreased cerebral blood flow velocity in apolipoprotein E epsilon4 allele carriers with mild cognitive impairment. Eur. J. Neurol. 14, 150-155. doi:10.1111/j. 1468-1331.2006.01579.x

Sztriha, L. K., Nemeth, D., Sefcsik, T., and Vecsei, L. (2009). Carotid stenosis and the cognitive function. J. Neurol. Sci. 283, 36-40. doi:10.1016/j.jns.2009.02.307

Teague, S. M., and Sharma, M. K. (1991). Detection of paradoxical cerebral echo contrast embolization by transcranial Doppler ultrasound. Stroke 22, 740-745. doi:10.1161/01.STR.22.6.740

Touboul, P. J., Hennerici, M. G., Meairs, S., Adams, H., Amarenco, P., Bornstein, N., et al. (2012). Mannheim carotid intima-media thickness and plaque consensus (2004-2006-2011). An update on behalf of the advisory board of the 3rd, 4th and 5 th watching the risk symposia, at the 13th, 15th and 20th European Stroke Conferences, Mannheim, Germany, 2004, Brussels, Belgium, 2006, and Hamburg, Germany, 2011. Cerebrovasc. Dis. 34, 290-296. doi:10.1159/000343145

van Es, A. C., van der Grond, J., ten Dam, V. H., de Craen, A. J., Blauw, G. J., Westendorp, R. G., et al. (2010). Associations between total cerebral blood flow and age related changes of the brain. PLoS ONE 5:e9825. doi:10.1371/journal.pone. 0009825

van Oijen, M., de Jong, F. J., Witteman, J. C., Hofman, A., Koudstaal, P. J., and Breteler, M. M. (2007). Atherosclerosis and risk for dementia. Ann. Neurol. 61, 403-410. doi:10.1002/ana.21073

Vicenzini, E., Ricciardi, M. C., Altieri, M., Puccinelli, F., Bonaffini, N., Di Piero, V., et al. (2007). Cerebrovascular reactivity in degenerative and vascular dementia: a transcranial Doppler study. Eur. Neurol. 58, 84-89. doi:10.1159/000103642

Viticchi, G., Falsetti, L., Vernieri, F., Altamura, C., Bartolini, M., Luzzi, S., et al. (2012). Vascular predictors of cognitive decline in patients with mild cognitive impairment. Neurobiol. Aging 33, e1-e9. doi:10.1016/j.neurobiolaging.2011.11.027

Wolf, H., Ecke, G. M., Bettin, S., Dietrich, J., and Gertz, H. J. (2000). Do white matter changes contribute to the subsequent development of dementia in patients with mild cognitive impairment? A longitudinal study. Int. J. Geriatr. Psychiatry 15, 803-812. doi:10.1002/1099-1166(200009)15:9<803::AIDGPS190>3.3.CO;2-N

Wollman, D. E., and Prohovnik, I. (2003). Sensitivity and specificity of neuroimaging for the diagnosis of Alzheimer's disease. Dialogues Clin. Neurosci. 5, 89-99.

Wu, C. C., Mungas, D., Petkov, C. I., Eberling, J. L., Zrelak, P. A., Buonocore, M. H., et al. (2002). Brain structure and cognition in a community sample of elderly Latinos. Neurology 59, 383-391. doi:10.1212/WNL.59.3.383

Yamaguchi, F., Meyer, J. S., Yamamoto, M., Sakai, F., and Shaw, T. (1980). Noninvasive regional cerebral blood flow measurements in dementia. Arch. Neurol. 37, 410-418. doi:10.1001/archneur.1980.00500560040003 
Zavoreo, I., Basic Kes, V., Lisak, M., Marsic, N., Ciliga, D., and Trost Bobic, T. (2013). Cognitive decline and cerebral vasoreactivity in asymptomatic patients with severe internal carotid artery stenosis. Acta Neurol. Belg. 113, 453-458. doi:10.1007/s13760-013-0196-4

Conflict of Interest Statement: The authors declare that the research was conducted in the absence of any commercial or financial relationships that could be construed as a potential conflict of interest.

Received: 27 September 2013; accepted: 03 January 2014; published online: 21 January 2014.
Citation: Urbanova B, Tomek A, Mikulik R, Magerova H, Horinek D and Hort $J$ (2014) Neurosonological examination: a non-invasive approach for the detection of cerebrovascular impairment in AD. Front. Behav. Neurosci. 8:4. doi: 10.3389/fnbeh.2014.00004

This article was submitted to the journal Frontiers in Behavioral Neuroscience.

Copyright (c) 2014 Urbanova, Tomek, Mikulik, Magerova, Horinek and Hort. This is an open-access article distributed under the terms of the Creative Commons Attribution License (CC BY). The use, distribution or reproduction in other forums is permitted, provided the original author(s) or licensor are credited and that the original publication in this journal is cited, in accordance with accepted academic practice. No use, distribution or reproduction is permitted which does not comply with these terms. 